\title{
Direct Organogenesis of Passiflora foetida L. through Nodal Explants
}

\section{S.P. Anand ${ }^{* 1}$, E. Jayakumar, R. Jeyachandran, V. Nandagobalan ${ }^{1}$ and A. Doss ${ }^{1}$}

Department of Botany, St. Joseph's College (Autonomous), Tiruchirappalli-620 002,

Tamil Nadu, India

Key words: Passiflora foetida, Node explant, Direct organogenesis

Passiflora foetida L. belongs to the family Passiflroaceae, one of the best known remedies for asthma and biliousness, is cultivated in different parts of India. It was regenerated from nodal explants through direct organogenesis without intervening callus phase. High frequency multiple shoots were formed on MS supplemented with $2.0 \mathrm{mg} / \mathrm{l} \mathrm{BAP}+1.0 \mathrm{mg} / \mathrm{l} \mathrm{Kn}$ with $85 \%$ of survival rate. Maximum range of shoot elongation was successfully obtained on MS with 1.5 $\mathrm{mg} / \mathrm{l} \mathrm{BAP}+0.5 \mathrm{mg} / \mathrm{l} \mathrm{NAA}$. The best root induction was found on $0.5 \mathrm{mg} / \mathrm{l} \mathrm{NAA}+$ $0.5 \mathrm{mg} / \mathrm{l} \mathrm{IBA}$. This protocol seems to have enough potentiality for micropropagation of this valuable germplasm.

The use of medicinal plants is increasing world-wide. According to the World Health Organization (WHO), approximately $80 \%$ of the world's population currently use herbal medicines directly as tea, decocts or extracts with easily accessible liquids such as water, milk, or alcohol (Julsing et al. 2007). In vitro cell and tissue culture methodologies are envisaged as a mean for germplasm conservation to ensure the existantance of endangered plant species, rapid mass propagation for large scale regeneration, and for genetic manipulation studies. Combinations of in vitro propagation techniques (Fay 1992) may help in conservation of biodiversity of locally used medicinal plants. In-vitro propagation of plants holds tremendous potential for the production of high-quality plant-based medicines (Murch et al. 2000).

Passiflora foetida (L.) is an important medicinal plant. In English it is called as stinking passion flower or wild water lemon or love-in-a-mist flower plant and in Tamil. It is dialect as mosukkattaan or poonaipidukku. It has been introduced to

*Author for correspondance. ${ }^{1} \mathrm{PG}$ and Research Department of Botany, National College (Autonomous), Tiruchirappalli - 620 001. Tamil Nadu, India. 
tropical regions of the world, The specific name, foetida, means "stinking" in Latin and refers to the strong aroma emitted by damaged foliage (Nellis 1997). It is a herbaceous climber emitting a foetial smell when bruised. It is distributed in several parts of India at plains from the coast and abundant on river bed. Flowers during November-May. Fruits normally found in February onwards. It is in orange colour when ripes (Matthew 1983).

Passiflora foetida having the numerous medicinal properties such as, fruits are said to be emetic and a decoction of them is used for asthma and biliousess, leaves are used as dressing for wounds, roots are said to be an emmenagogue and useful in hysteria and curing itches. The fruits are edible when ripe. But unripe fruits are poisonous and contain a cyanogenic glucoside. The edible portion of the ripe fruit contains $12 \%$ ash, $10 \mathrm{mg}$ calcium, $6 \mathrm{mg}$ phosphorus, $0.8 \mathrm{mg}$ iron, $0.4 \mathrm{mg} / 100 \mathrm{mg}$ niacin. Peelings of the fruits, seeds and leaves contain an unstable compound which yields hydrocyanic acid and acetone (Deshaprabhu 1966). Plants yield an edible fruit, the fruits are eaten. Young leaves and plant tips are edible. Dry leaves are used in tea in Vietnamese folk medicine to relieve sleeping problems. P. foetida is able to trap insects on its bracts, which exude a sticky substance that also contains digestive enzymes. This minimizes predation on young flowers and fruits (Radhamani et al. 1995).

The whole plants were collected by plucking with roots from the bank of river Kollidam in Tiruchirappalli, Tamil Nadu, India. They were replanted in Botanical Garden of St. Joseph's College, Tiruchirappalli, India.

Node explants were used for direct organogenesis in MS supplemented with 2,4-D, NAA, IAA and $\mathrm{Kn}$ was also used at $0.5-5.0 \mathrm{mg} / \mathrm{l}$.

Cultures were maintained at $25 \pm 2^{\circ} \mathrm{C}$ at $16 \mathrm{hrs}$ light and $8 \mathrm{hrs}$ dark per day of fluorescent light (2000 - 3000 lux) for all treatments. Subcultures were made on the same medium after 15 days.

The rooted plantlets were removed from the culture tubes and washed in running tap water. Then they were transplanted into plastic cups containing sterilized vermiculite. The plants were covered with plastic bags with perforations or holes. After 15 days the plantlets in the plastic cups were transferred to a shadow for about 30 days and then transferred to the soil.

The nodal explants were cultured on MS supplemented with BAP $(2.0 \mathrm{mg} / \mathrm{l})$ $+\mathrm{Kn}(1.0 \mathrm{mg} / \mathrm{l})$ (Fig. 1A, Table 1) produced high range of multiple shoot (36.33 \pm 5.90) buds after 20 days. Abubacker and Ramanathan (2004) reported that MS fortified with BAP and Kn was suitable for best shoot regeneration.

Best shoot elongation was obtained from nodal explants in MS supplimented with $1.5 \mathrm{mg} .1 \mathrm{BAP}+0.5 \mathrm{mg} / \mathrm{l}$ NAA (Fig. 1C). Similar results were reported by Mohapatra and Rath (2005) in Baccopa moniera. 

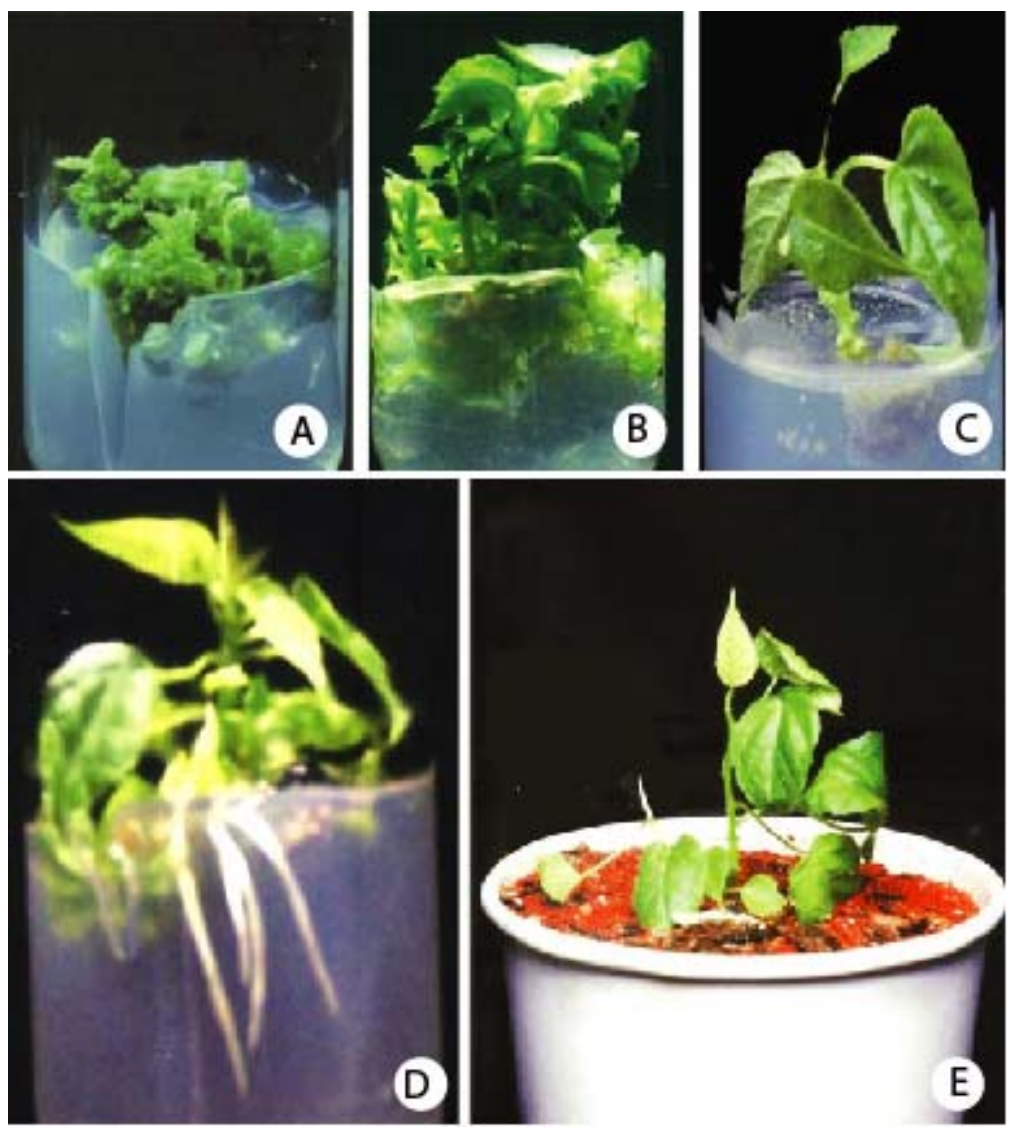

Fig. 1. Micropropagation of nodal explant of Passiflora foetida L. A. Multiple shoot formation on MS + $2.0 \mathrm{mg} / \mathrm{l} \mathrm{BAP}$ and $1.0 \mathrm{mg} / \mathrm{Kn}$. B. Maturation of multiple shoots on $\mathrm{MS}+1.5 \mathrm{mg} / \mathrm{l} \mathrm{BAP}$ and $0.5 \mathrm{mg} / \mathrm{l} \mathrm{NAA}$. C. Shoot elongation on $\mathrm{MS}+1.5 \mathrm{mg} / \mathrm{l} \mathrm{BAP}$ and $0.5 \mathrm{mg} / 1 \mathrm{NAA}$. D. Root proliferation on $\mathrm{MS}+0.5 \mathrm{mg} / \mathrm{l} \mathrm{NAA}$ and $0.5 \mathrm{mg} / \mathrm{l} \mathrm{IBA}$. E. Acclamatized plantlet.

Table 1. Response of the Passiflora foetida nodal explants for the production of multiple shoots in BAP and Kn.

\begin{tabular}{|c|c|c|}
\hline \multicolumn{2}{|c|}{ Hormone conc. (mg/l) } & \multirow{2}{*}{$\begin{array}{l}\text { Multiple shoots from nodal } \\
\text { explant }(\text { Mean } \pm S d)\end{array}$} \\
\hline BAP & $\mathrm{Kn}$ & \\
\hline 1.5 & 0.5 & $28.33 \pm 2.86$ \\
\hline 2.0 & 1.0 & $36.33 \pm 5.90$ \\
\hline 3.0 & 1.5 & $25.66 \pm 3.29$ \\
\hline 4.0 & 2.0 & $15.66 \pm 3.29$ \\
\hline
\end{tabular}

The elongated shootlets derived from node of Passiflora foetida were transferred on to MS supplemented with different concentrations of NAA + IBA. 
The best root induction was found on $0.5 \mathrm{mg} / \mathrm{l}$ NAA $+0.5 \mathrm{mg} / \mathrm{l}$ IBA (Fig. 1D \& Table 2). Binoy and Kumar (2004) reported similar in Ophiorrhiza mungo.

Table 2. Root induction from the Passiflora foetida nodal explants with various concentrations of IBA and IAA

\begin{tabular}{ccc}
\hline \multicolumn{2}{c}{ Hormone conc. $(\mathrm{mg} / \mathrm{l})$} & Node \\
\cline { 1 - 2 } IBA & NAA & \\
\hline 0.1 & 0.1 & - \\
0.2 & 0.2 & - \\
0.3 & 0.3 & ++ \\
0.4 & 0.4 & +++ \\
0.5 & 0.5 & ++++ \\
0.6 & 0.6 & +++ \\
\hline \multirow{2}{*}{$+++=$ High,$+++=$ Moderate,$++=$ Poor,$-=$ Nil. }
\end{tabular}

The rooted plantlets were removed from the culture tubes and washed to free MS liquid media. They were then transferred into tea cups containing vermiculite and sterilized soil (1:1) for acclimatization (Fig. 1E). The survival rates of the hardened plants were found to be $85 \%$.

The present study describes a well documented and reliable protocol of Passiflora foetida from nodal explants with much higher rate of multiplication. This protocol can be used as a basic tool for commercial cultivation of stinking passion flower plant.

\section{References}

Abubacker MN and Ramanathan R (2004) In vitro shoot regeneration from various explants of Trichosanthes perroffetiana Cogn-Monog - A medicinal plant. Ad. Plant Sci. 17: 11-16.

Binoy Jose and Satheesh Kumar K (2004) In vitro multiplication of Ophiorrhiza mungo Linn. Indian J. Exp. Biol. 42: 639-642.

Deshaprabhu SB (1966). The wealth of India - A dictionary of Indian raw materials and industrial research, Vol. VII: N-pe. Publications \& information directorate, CSIR New Delhi. pp.278.

Fay MF (1992). Conservation of rare and endangered plants using in vitro methods. In Vitro Cell Dev. Biol. Plant 28: 1 - 4.

Julsing K Matthys, Quax J Wim and Kayser Oliver (2007) The Engineering of Medicinal Plants: Prospects and Limitations of Medicinal Plant Biotechnology. In: Oliver Kayser and Wim J. Quax, ed. Medicinal Plant Biotechnology. WILEY-VCH Verlag GmbH \& Co. KGaA, Weinheim 2007; 978-3-527-31443-0 
Matthew KM (1983) The Flora of the Tamil Nadu Carnatic. Part I (Polypetalae). The Rapinat Herbarium, St. Joseph's College, Tiruchirappalli, India. Diocesan Press, Madras, pp. 630.

Mohapatra HP and Rath SP (2005) In vitro studies of Bacopa monnierl an important medicinal plant with reference to its biochemical variations. Indian J. Exp. Biol. 43: 373-376.

Murch SJ, Krishna Raj S and Saxena PK (2000) Tryptophan is a precursor for melatonin and serotonin biosynthesis in in-vitro regenerated St. John's wort (Hypericum perforatum L. cv. Anthos) plants. Plant Cell. Rep. 19: 698-704.

Nellis DW (1997) Poisonous Plants and Animals of Florida and the Caribbean. Pineapple Press Inc. p. 224.

Radhamani TR, Sudarshana L and Rani Krishnan (1995) Defense and carnivory: Dual role of bracts in Passiflora foetida. J. Biosci. 20(5): 657-664. 